\title{
Detection of diatoms in the marrow of thigh bones as evidence of death by drowning
}

The advantage of detecting diatoms in bone marrow (diatom test), is that it could be used in coming to a conclusion about suspected death by drowning in severely putrefied bodies where the usual signs of drowning are not present (1). However, the diatom test is controversial, with opponents and champions (2). According to some the diatom test provides the most reliable test of death by drowning (3). With the rapid onset of putrefaction in Sri Lanka, the classical features of drowning disappear quickly and detection of diatoms is bone marrow may be the only method available to detect death due to drowning. In this study, bone marrow from suspected cases of drowning were digested with concentrated nitric acid, whereby all organic matter was destroyed, leaving the siliceous bilaterally symmetrical shells of diatoms intact, and the deposits were examined under the microscope at a magnification of 400 . The bone marrow was selected because of its unlikely ennvironmental contamination.

\section{Methods}

The study included 14 cases, and in 11 the bodies were putrefied. The thigh bone was not removed but a window measuring $2 \mathrm{~cm} \times 1 \mathrm{~cm}$ was removed from the anterior of the thigh bone, the marrow was removed and examined for diatoms by the method described by Timperman (3). All the instruments used in all procedures were thoroughly cleaned in de-ionised water and were dried in an autoclave.

Marrow specimens were boiled for 12 hours continuously inside a fume cupboard and the specimens were examined at one-hour intervals. Nitric acid was added intermittently to prevent drying. When the residue in the crucible was converted to black, distilled water was added to immerse the residue in the crucible. The solution in the crucible was then centrifuged at 5000 revolutions per minute for 5 minutes. The supernatant clear fluid was removed with a pipette and the residue from each was examined for diatoms on a fresh glass slide under a coverslip. It was examined under a magnification of 400 using the strip search technique commencing from top left end of the area of the slide under the coverslip. Bone marrow was removed from the thighbone in two fresh autopsy cases, which were taken as control samples, where the cause of death was natural. Distilled water was used at all stages of the study. A sample of distilled water was also examined and there were no diatoms in it.

The diatoms were identified by their bilaterally symmetrical nature, refractibility of the siliceous capsules and the shapes. Some were tubular, others were oval or spindle shaped.

A sample of water from the well was examined in cases where the body was found in a well. In cases where the body was found on the beach or in a river, samples or water from these places were also examined for diatoms

Diatoms were found in $9(64.3 \%)$ of the 14 cases of suspected drowning, even when a single slide was examined. In all cases where diatoms were seen, the single field of vision of the microscope showed several diatoms, and the count was more than five. In 7 of these cases the body was putrefied to degrees varying from moderate to severe, and the other 2 were fresh cases. Diatoms were detected in the water from the site where the body was found in all cases where the bone marrow showed the presence of diatoms. In one case diatoms were present in the water from the public well where the body was recovered, but diatoms were not detected in the bone marrow even though the cause of death was drowning. In 5 cases the body was found on the beach. Water from the sea taken from a place close to where the body was found showed diatoms, and the shapes of the diatoms were tubular and oval bivalve.

Diatoms are microscopic algae present in sea water and unpolluted natural fresh waters. All diatoms have an indestructible siliceous capsules. Diatoms inhaled into the lungs when a person is drowned reach the alveoli, where they penetrate the alveolar walls and are carried in the circulation to the systemic organs such as the bone marrow, brain, and kidney while the heart is still beating (2). My study shows that diatoms are present in a majority of cases (63\%) where death was due to drowing. Of the 11 putrefied cases, $6(54.5 \%)$ showed diatoms in the bone marrow. The two cases where death was due to indisputable drowning, without diatoms in bone marrow, but present in the well, may be explained by death due to reflex vagal inhibition (dry drowning). In 4 cases, drowning was in a well, and both tubular and oval bivalve shaped diatoms were seen in the water.

My study also shows that embalming and burial have no effect on the detection of diatoms in the bone marrow in cases or drowning.

Whatever the opponents say, examination of marrow from the thigh bone, using instruments cleaned in distilled water, is an easy, economical and efficient way to establish death by drowning, especially when the body is putrefied. Testing for diatoms in the water in which the person drowned is also useful, if it is found that the types of diatoms are similar. 
Table. Summary of results of diatom test for drowning

\begin{tabular}{|c|c|c|c|c|c|}
\hline $\begin{array}{l}\text { Serial } \\
\text { number }\end{array}$ & $\begin{array}{l}\text { Diatoms in } \\
\text { bone } \\
\text { marrow }\end{array}$ & $\begin{array}{l}\text { Medium of } \\
\text { suspected } \\
\text { drowning }\end{array}$ & $\begin{array}{c}\text { Condition of body } \\
\text { and } \\
\text { cause of death }\end{array}$ & $\begin{array}{l}\text { 1st or } 2 \text { nd } \\
\text { potmortem }\end{array}$ & $\begin{array}{l}\text { Shape of } \\
\operatorname{diatom}(s)\end{array}$ \\
\hline 1 & Present & River & $\begin{array}{l}\text { Putrefied, } \\
\text { drowning }\end{array}$ & $\begin{array}{l}\text { 2nd, after } \\
\text { embalming }\end{array}$ & Oval \\
\hline 2 & Absent & River & $\begin{array}{l}\text { Severely putrefied, } \\
\text { drowning }\end{array}$ & $1 \mathrm{st}$ & - \\
\hline 3 & Present & Sea & $\begin{array}{l}\text { Putrefied, } \\
\text { drowning }\end{array}$ & $\begin{array}{l}\text { 2nd after } \\
\text { exhumation }\end{array}$ & Tubular \\
\hline 4 & Present & Well & $\begin{array}{l}\text { Fresh, } \\
\text { drowning }\end{array}$ & $1 \mathrm{st}$ & $\begin{array}{c}\text { Tubular and } \\
\text { oval }\end{array}$ \\
\hline 5 & Absent & Sea & $\begin{array}{c}\text { Putrefied, } \\
\text { unascertainable }\end{array}$ & $1 \mathrm{st}$ & - \\
\hline 6 & Present & Lake & $\begin{array}{l}\text { Severely decomposed } \\
\text { drowning }\end{array}$ & lst & Tubular \\
\hline 7 & Present & Well & $\begin{array}{l}\text { Fresh, } \\
\text { drowning }\end{array}$ & $1 \mathrm{st}$ & Oval \\
\hline 8 & Absent & River & $\begin{array}{c}\text { Putrefied, } \\
\text { unascertainable }\end{array}$ & $\begin{array}{l}\text { 2nd, after } \\
\text { exhumation }\end{array}$ & - \\
\hline 9 & Present & Sea & $\begin{array}{l}\text { Putrefied, } \\
\text { drowning }\end{array}$ & $\begin{array}{l}\text { 2nd, after } \\
\text { exhumation }\end{array}$ & Tubular \\
\hline 10 & Absent & Well & $\begin{array}{l}\text { Putrefied, } \\
\text { drowning }\end{array}$ & $1 s t$ & - \\
\hline 11 & Absent & Well & $\begin{array}{l}\text { Mildly putrefied, } \\
\text { drowning }\end{array}$ & $1 \mathrm{st}$ & Bivalve type \\
\hline 12 & Present & Sea & $\begin{array}{l}\text { Mildly putrefied } \\
\text { drowning }\end{array}$ & 1 st & Tubular \\
\hline 13 & Present & Sea & $\begin{array}{l}\text { Fresh, } \\
\text { drowning }\end{array}$ & $1 \mathrm{st}$ & $\begin{array}{c}\text { Bivalve type, } \\
\text { oval }\end{array}$ \\
\hline 14 & Present & Canal & $\begin{array}{l}\text { Putrefied, } \\
\text { drowning }\end{array}$ & $1 \mathrm{st}$ & Bivalve type \\
\hline
\end{tabular}

\section{References}

1. Knight B. Forensic Pathology. 1st ed. London: Edward Amold, 1992: 372.
2. Knight B, Ed. Simpson's Forensic Medicine. 11th ed. London: Amold, 1997: 99.

3. Timperman $J$. The detection of diatoms in the marrow of the sternum. Journal of Forensic Medicine 1962; 9: 134-6.

Niriellage Chandrasiri, Senior Professor of Forensic Medicine, Faculty of Medicine, University of Ruhuna. 